\title{
SPIRITUALITAS MURIA: Akomodasi Tradisi dan Wisata
}

\author{
Ahmad Falah \\ STAIN Kudus \\ e-mail: a_falah@yahoo.com
}

\begin{abstract}
Tradition of "nyekar" which is very familiar among Javanese society, especially in the grave yard Muria Kudus Central Java. This research revealed that most of the visitor of the grave are for getting tabarrukan, some kind safety and ease in any effort in their life, mastering any knowledge, and linuwih, getting for healing from any desease, and asking for blessing for their descendants. The visit to the grave impacted much to the society living, both economically and socially. In the perspective of economy, more than 1.500 force workers depended much the existence of Muria. The other impact are the local solidarity, social competition, and job opportunity, that resulted in the growth of pragmatism among Muria society members.
\end{abstract}

\begin{abstract}
***
Tradisi "nyekar" sangat dikenal oleh orang Jawa, khususnya di makam Muria Kudus Jawa Tengah. Penelitian ini mengungkap bahwa kebanyakan peziarah makam ini bertujuan untuk mendapatkan keberkahan (tabarrukan), keamanan dan kemudahan dalam hidup, menguasai ilmu linuwih, disembuhkan dari penyakit, dan mengharapkan kebaikan dari nenek moyang. Kunjungan mereka ke makam itu memberikan dampak yang besar bagi kehidupan masyarakat, baik secara ekonomi maupun sosial. Dalam perspektif ekonomi, lebih dari 1.500 tenaga kerja tergantung pada keberadaan makam Muria. Dampak yang lain adalah slidaritas setempat, kompetisi sosial, dan kesempatan kerja yang mengakibatkan munculnya tumbuhnya pragmatisme di kalangan anggota masyarakat Muria.
\end{abstract}

Keywords: Muria, nyekar, tabarrukan, makam, blessing 


\section{A. Pendahuluan}

Bukan saja keindahan alamnya, Gunung Muria dikenal oleh masyarakatnya sebagai tempat "seribu makam keramat". Ada banyak makam "keramat" di tempat tersebut. Bahkan makam Raden Said atau biasa dikenal Sunan Muria—salah satu Walisongo ${ }^{1}$ - terdapat di salah satu puncak gunung tersebut. Di samping terdapat makam Sunan Muria, juga terdapat makam yang dianggap mempunyai "tuah", seperti Makam Sunan Gading, Makam Sunan Gadung, Makam Syeikh Hasan Sadzili dan Makam Rejenu Muria yang dianggap sebagai cikal bakal masyarakat Muria. Makam-makam tersebut seakan tidak pernah sepi dari para peziarah dalam setiap harinya.

"Nyekar" ke makam-makam "suci" yang terletak di Gunung Muria, merupakan "budaya" yang dikaitkan dengan kreasi para wali atau penyebar Islam awal di Jawa. Motif untuk melakukan tindakan tersebut adalah untuk memperoleh berkah. Melalui bagan konseptual in order to motive atau untuk memperoleh berkah, ternyata juga penting dilihat dari bagan konseptual because motive atau orang pergi ke tempat keramat adalah disebabkan oleh keyakinan bahwa "medan-medan" budaya tersebut mengandung sakralitas, mistis dan magis. Namun demikian, keduanya tidak cukup untuk menganalisis tindakan itu, maka diperlukan bagan konseptual pragmatic motive yaitu orang pergi ke medan budaya disebabkan oleh adanya motif pragmatis atau kepentingan yang mendasar di dalam kehidupannya.

Konsep tawasul (mediasi) dan mutawasul (mediator) digerakkan oleh sistem berpikir bipolar tentang Tuhan - manusia, yaitu: atas - bawah; suci kotor; sakral - profan; dan jauh - dekat. Sistem klasifikasi simbolik yang dipakai untuk menjelaskan tingkat atau bentuk hubungan Tuhan - manusia dalam perwujudan seperti ini, menuntun mereka untuk menciptakan mo-

1 Walisongo dikenal sebagai wali yang berjasa menyebarkan Islam di tanah Jawa dan sekitarnya. Mereka jumlahnya ada sembilan wali. Antara lain Sunan Maulana Malik Ibrahim, Sunan Bonang, Sunan Derajat, Sunan Giri, Sunan Ampel, Sunan Kudus, Sunan Muria, Sunan Kalijaga dan Sunan Gunung Jati. Di samping makam Walisongo, makam-makam lain di sekitar Jawa Tengah yang sering dikunjungi peziarah antara lain Makam Sultan Fatah (Demak), Makam Sunan Pandanaran (Klaten), ataupun Makam Syeikh Muttamaqin (Pati). Informasi tentang Syekh Ahmad Mutamakkin dapat dibaca dalam: H.M. Imam Sanusi, Perjuangan Syaikh K.H. Ahmad Mutamakkin (Kajen-Pati: t.p, 1428H/2007); S. Soebardi, Serat Cabolek: Kuasa, Agama, Pembebasan: Pengadilan K.H. A. Mutamakin dan Fenomena Shaikh Siti Jenar, (Bandung: Nuansa, 2004). 
derasi (penengah) yang mengantarai, sehingga melahirkan klasifikasi tiga (trikotomi), (lihat gambar di bawah).

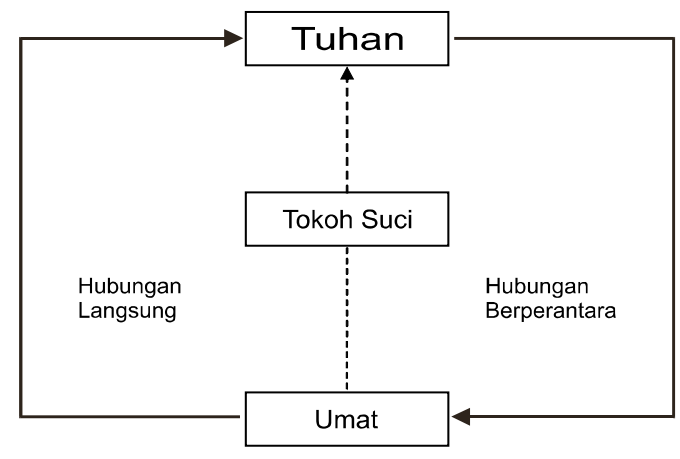

Gambar 1.

Trikotomi Pola Hubungan Tuhan - Manusia

Untuk mengarahkan penelitian, objek penelitian ini dirumuskan dalam dua hal. Pertama: penggalian ragam "in order to motive" para peziarah yang melatarbelakangi pelaksanaan tradisi "nyekar" pada "makam-makam keramat" di sekitar Gunung Muria. Kedua: penelusuran dampak sosial dan ekonomi dari tradisi "nyekar", terutama terkait dengan ranah wisata.

Metode penelitian ini meliputi teknik-teknik penelitian yang mencakup teknik pengumpulan data dan teknik analisis data. Teknik Pengumpulan Data menggunakan metode pengamatan dengan sentuhan participant observation dan uncontrolled observation. Wawancara mendalam (interview), dilakukan kepada terutama, pelaku atau person-person yang terlibat dalam penyelenggaraan ritual "nyekar", ditambah sumber lain yang dipilih dengan pertimbangan kemungkinannya sebagai sumber yang dapat memberikan informasi yang berkaitan.

Berdasarkan rumusan masalah dan tujuan penelitian ini, maka ruang lingkup penelitian ini termasuk ke dalam jenis penelitian kualitatif. Maka analisis data yang digunakan dalam penelitian ini adalah analisis kualitatif. Fenomenologi menjadi pilihan pendekatan yang akan digunakan sebagai tool of analysis, mengingat pendekatan ini memungkinkan analisis didasarkan pada penghayatan intuitif atau persi subjektif sebagaimana didapatkan dari 
pengamatan partisipatoris dan wawancara langsung yang mendalam. Fenomenologi di sini, yakni suatu penarikan kesimpulan dengan menggunakan setidaknya tiga langkah yaitu: interpretasi, ekstrapolasi dan meaning. ${ }^{2}$

\section{B. Ziarah ke Makam Muria: Antara Spiritualitas dan Tradisi}

Kondisi "krisis psikologis" manusia modern ini mendorong mereka untuk mencari medium-medium yang memungkinkan mereka bisa melakukan relaksasi secara psikologis dengan melakukan "olah spiritualitas", satu dimensi kemanusiaan yang justru teralienasi oleh modernitas. Ada banyak cara dan medium yang digunakan manusia untuk mengekspresikan kebutuhan spiritualitasnya. Salah satunya berkunjung ke tempat-tempat yang dianggap suci, termasuk ziarah ke makam-makam wali. Ziarah ke tempattempat yang dianggap keramat merupakan tradisi yang dilakukan sejak lama dan terus berlangsung hingga sekarang. Meski zaman modernisasi telah merasuki seluruh aspek kehidupan masyarakat, tetapi nilai-nilai tradisional seperti berziarah ke makam keramat tidak dapat terhapuskan begitu saja. Masyarakat meyakini bahwa ritual ziarah bukan saja bagian dari proses relaksasi secara spiritual, namun lebih dari itu, ritual tersebut bisa mengatasi persoalan kehidupan yang dihadapi oleh masyarakat modern. Karena itu, dimensi yang melekat dalam tradisi ziarah bersifat beragam sesuai dengan kecenderungan dan motif peziarah itu sendiri.

Di antara makam yang disakralkan dan sering dikunjungi oleh masyarakat adalah makam Sunan Muria di Colo Kudus serta beberapa makam yang dianggap suci di lereng Muria, seperti Sunan Gadung, Sunan Gading dan makam Syeh Sadzili. Setiap harinya selalu ada pengunjung yang berziarah, utamanya ke makam-makam tersebut. Menurut data tahun 2010 ini sudah lebih dari dua juta peziarah yang mengunjungi makam Sunan Muria. Puncak para peziarah biasanya pada bulan-bulan tertentu seperti Syuro atau Muharram, yakni pada saat buka luwur (penggantian kain penutup plafon makam) makam Kanjeng Sunan Muria. Sementara peziarah yang mengunjungi makam Sunan Gadung, Sunan Gading dan Syeh Sadzili ${ }^{3}$ selalu ada

\footnotetext{
2 Noeng Muhadjir, Metodologi Penelitian Kualitatif, (Yogyakarta: Rake Sarakin, 1996)

${ }_{3}^{3}$ Sejarah Syeh Sadzali masih penuh misteri. Pengurus sedang mengumpulkan data. Yang mereka yakini, Syeh itu salah satu murid Sunan Muria yang konon berasal dari Irak (Baghdad). Salah satu murid yang dikasihi karena memegang peranan penting ketika Sunan Muria adu kesaktian
} 
pada setiap harinya, hanya tidak sebanyak peziarah pada makam Sunan Muria. Para peziarah ke makam makam suci itu berasal dari berbagai wilayah di Indonesia, utamanya Jawa, seperti Demak, Pati, Jepara, Madura, Surabaya, Bandung dan Jakarta dan sebagainya. Personifikasi Sunan Muria yang dianggap sebagai "orang suci" serta kerabat dan santrinya yang juga dianggap sebagai orang-orang suci, menjadikan makam mereka menjadi pusat bagi aktivitas budaya masyarakat pendukungnya. Fenomena para peziarah yang tidak pernah surut mendatangi "makna suci" Sunan Muria menggambarkan bahwa makam tersebut berfungsi sebagai medium bagi pemuasan kebutuhan spiritualitas masyarakat dewasa ini.

Fenomena ziarah di atas berhubungan dengan konsep kewalian. Menurut Henri Chambert-Loir dan Claude Guillot, ${ }^{4}$ memandang bagaimana para wali membentuk sebuah jaringan rantai panjang yang melalui fenomena pengeramatannya, menghubungkan para peziarah dengan sang Ilahi. Dalam tradisi ziarah ke makam suci sebenarnya membawa pelakunya menjadi bagian dalam semesta misteri kegaiban tempat-tempat suci yang juga bagian dari bagaimana identitas itu dimaknai. Tidak sedikit tempat suci "baru" yang dipercaya sebagai pusat atau poros kehidupan yang lebih berkonotasi poros kesadaran spiritualitas. Terlebih lagi sesuatu yang sakral senantiasa bersifat komunal. Dalam konteks ini sakralitas makam Sunan Muria dan makammakam suci di lereng Muria tidak lagi sekedar karena hubungannya dengan masa lalu, tapi karena ribuan orang berkonsentrasi di tempat itu sehingga memancarkan "energi spiritual" tersendiri. Makam-makam wali dan para peziarah, akhirnya, adalah pertemuan yang kerap menakjubkan tentang bagaimana gejala spiritualitas itu menjadi sebuah tradisi tradisi yang bisa mengkonstruksi identitas para pendukungnya.

Menurut perspektif antropologi bahwa "pengkultusan" makam-makam suci di Semenanjung Muria yang diyakini sebagai makam-makam orang suci, telah membawa ingatan bersama pada segenap hubungan antara "orang suci" dan "tempat suci" dalam pemaknaan ruang dan waktu. Tidak ada satu pun

dengan Dampo Awang. Karena banyak yang iri kemudian tersisih atau disisihkan. Ada dugaan dia menyingkir ke tempat dia dimakamkan sekarang ini di Rejenu. Kompleks makam ini memang banyak mengandung misteri karena masih banyak makam yang belum dikenali.

4 Henri Chambert-Loir dan Claude Guillot, Ziarah dan Wali di Dunia Islam, (Jakarta: Serambi, Forum Jakarta Paris dan EFEO, 2003). 
tempat suci dalam tradisi ritus agama-agama besar yang tidak berhubungan dengan peristiwa bersejarah dalam hidup orang-orang suci, sebutlah nabi dan rasul. Tempat atau tanah suci inilah yang kemudian tidak sekadar dipercaya sebagai kutub dari seluruh kesadaran transenden, namun juga yang lantas berkaitan dengan ihwal identitas budaya. Penyebaran Islam ke berbagai belahan dunia telah membuat tanah suci (Mekkah) semakin jauh dan mistis, sehingga membuat umatnya menciptakan tempat-tempat suci baru yang dianggap cerminan dari tanah suci yang sebenarnya. Karena itulah, menurut peneliti, sesungguhnya hanya satu tempat saja yang ditunjuk oleh sejarah sebagai "tanah suci" yakni Makkah dan Madinah-atau lazim disebut haramain, tetapi faktanya umat terus memperbanyak jumlah itu, dengan menciptakan peta kesucian "baru". Proses penghadiran peta kesucian baru ini meniscayakan hubungannya dengan identitas pengeramatan manusia yang kemudian disebut sebagai "wali". Oleh karena dalam Islam tidak ada lembaga yang bertugas mengesahkan kewalian, masyarakatlah yang mengangkatnya menjadi wali yang erat kaitannya dengan jaringan kehidupan "tarekat" atau sufism serta yang secara genealogis merujuk pada kesucian Nabi Muhammad SAW. sebagai kutub dari seluruh identifikasi orang suci. Para wali tentu saja merupakan pewaris spiritual Rasulullah, akan tetapi mereka bukanlah jembatan langsung dengan nabi yang didambakan itu. Lantaran itu, setiap golongan manusia mereka-reka berbagai silsilah buatan guna menghubungkan para wali mereka langsung dengan Rasulullah SAW.

Satu hal yang selalu terdapat di berbagai tempat suci adalah keberadaan air "keramat" yang diyakini mengalir dari masa lampau bersama kesucian tempat itu. Pada tempat-tempat suci umat Islam, agaknya hal ini untuk mengutuhkan seluruh replika tentang Makkah dengan keberadaan air zamzamnya. Dalam sistem kepercayaan masyarakat Islam, kesucian Makkah melekat dalam sifat air zamzam. Replika kesucian zam-zam di Makkah tampaknya juga menjadi fenomena yang muncul di tempat-tempat makam wali yang diyakini suci, termasuk di makam Sunan Muria. Di makam ini "air suci" sebagai replica zamzam di Makkah disediakan oleh pengelola makam dan ditaruh di gentong-gentong kuno peninggalan Kanjeng Sunan dan diletakkan di sekitar makam. Biasanya para peziarah setelah melakukan ritual, mengambil air untuk diminum atau sekedar untuk membasuh muka dan tidak 
sedikit peziarah yang mengambilnya untuk dibawa pulang dan digunakan sebagai media obat atau kepentingan lainnya. Di samping "air" makam Sunan Muria yang sering dimanfaatkan para peziarah, terdapat juga jenis mata air di Gunung Muria yang juga diyakini berkhasiat karena karamah kewalian, yakni "air tiga rasa". Air tiga rasa ini boleh dibilang ajaib, karena air ini memiliki rasa seperti minuman khas, ketajaman rasa antara satu dengan lainnya berbeda. Banyak orang yang datang untuk mengambil air itu sebagai obat atau kepentingan lainnya. Konon banyak juga paranormal memanfaatkan air tiga rasa untuk obat penyembuhan. Sebagian peziarah mempercayai bahwa, dengan minum air itu jiwa mereka menjadi lebih tenang, rasa percaya diri mereka lebih tebal dan badan menjadi lebih sehat.

Makam Kanjeng Sunan Muria dan para wali adalah tempat pengungkapan perasaan spiritual (religius) yang bebas serta juga tempat memelihara ritus-ritus kuno yang mempunyai landasan sejarah kuat pada masyarakat Jawa. Sebagai media spiritual (religious), praktek mengunjungi makam wali dipandang sebagai amal yang mempunyai nilai ibadah, pada sisi lain praktek ini mempunyai landasan historis sebagai tradisi yang keberlangsungannya telah mengakar sebagai konsepsi kebudayaan masyarakat pada umumnya. Dalam konteks masyarakat Jawa, ziarah ke makam suci sebenarnya telah menjadi bagian dari tradisi leluhur yang diwarisinya jauh sebelum Islam datang. ${ }^{5}$ Bahkan menurut Purwadi (2007) bahwa ziarah ke makam wali, kata Purwadi, merupakan kepanjangan dari tradisi Hinduisme bernama upacara srada. Tradisi ini sudah ada pada masa pemerintahan Hayam Wuruk, raja yang memerintah Majapahit sekitar pertengahan abad ke-14. Srada adalah upacara untuk memuliakan leluhur yang sudah meninggal. Dari kata srada itulah, masyarakat Jawa mengenal nyadran, yaitu kegiatan menziarahi makam leluhur. Biasanya nyadran ini dilakukan mendekati bulan puasa. Jadi, ziarah makam ini adalah bentuk akulturasi budaya Hindu dan Islam. Akulturasi budaya memang sudah dilakukan para wali untuk menyiarkan agama Islam pada masa itu.

${ }^{5}$ Sebagian besar masyarakat Jawa telah memiliki suatu agama secara formal, namun dalam kehidupannya masih nampak adanya suatu sistem kepercayaan yang masih kuat dalam kehidupan religinya, seperti kepercayaan terhadap adanya dewa, makhluk halus, atau leluhur, (Koentjaraningrat, 1994: 105). 
Keseluruhan tradisi dan budaya Jawa, termasuk ziarah ke makam suci bisa dikatakan sebagai sarana pengikat bagi orang Jawa yang memiliki status sosial yang berbeda dan begitu juga memiliki keyakinan yang berbeda. Kebersamaan di antara mereka tampak ketika pada momen-momen tertentu mereka mengadakan upacara-upacara (perayaan) baik yang bersifat ritual maupun seremonial yang sarat dengan nuansa keagamaan. Peziarah di makam Sunan Muria jika dikategorikan dari status sosial peziarah tercatat dari status sosial paling rendah sampai pejabat Negara bahkan presiden. Mereka datang ke makam Sunan Muria dengan tujuan sama yakni berziarah dan membaca doa, walaupun status dan motif mereka bisa berbeda. Sungguh pun tradisi ini sekarang ada di pusaran modernisasi dan rasionalisasi, namun faktanya tradisi seperti ini sampai sekarang masih bertahan, terutama di Jawa, bahkan kegiatan ini menjadi agenda tersendiri dalam memenuhi kegiatan keagamaan. Munculnya motif di luar tujuan utama ziarah, terlebih ketika sudah diiringi dengan praktik-praktik yang meniru tradisi pra-Islam, sehingga tidak pelak timbul tudingan yang berdasar pada suatu pandangan yang menganggap "syirik" dalam fenomena ziarah ini.

\section{Motive In Order Pelaku Ziarah ke Makam Muria}

Ziarah adalah sebuah aktivitas yang mempunyai tujuan-tujuan yang lahir dari motivasi para pengamalnya. Motivasi ini menjadi faktor penting untuk menganalisa motive in order apa saja yang melatari orang untuk melakukan ritual ziarah ke makam-makam suci. Mencermati apa yang terjadi dalam fenomena ziarah pada makam-makam suci di Semenanjung Muria, menurut peneliti, terdapat motif-motif-adakalanya yang bersifat kolektif ataupun motif yang bersifat personal. Dalam motif yang bersifat kolektif, Gerungan (1987) berpandangan bahwa dorongan atau motif bersama itu menjadi pengikat dan sebab utama terbentuknya kelompok sosial. Tanpa adanya motif yang sama antara sejumlah individu itu akan sukar terbentuk kelompok sosial yang khas. Gejala inilah yang kemudian melatari identitas sosial budaya pelaku ziarah. Sementara motif yang bersifat personal bentukannya menjadi sangat beragam, tergantung kecenderungan para peziarah.

Pandangan teologis tentang kemampuan wali bisa memberikan berkah dan manfaat ini yang kemudian melahirkan motif-motif para pelaku ziarah yang bersifat personal. Motif ini lebih bersifat biogenetis yakni motif yang 
berkembang pada diri manusia dan berasal dari organismenya sebagai makhluk biologis dan motif-motifnya berasal dari lingkungannya. Ada banyak maksud dan tujuan yang bersifat personal dari masing-masing peziarah. Motif ini tidak lepas dari credo tentang kewalian yang meyakini bahwa Sunan tertentu mempunyai manfaat pada penyelesaian kepentingan tertentu. Menurut pengamatan dan hasil wawancara terhadap para pelaku ziarah yang sempat peneliti temui di Muria, beberapa motive in order pelaku ziarah diantaranya: pertama, berkah agar hasil panennya melimpah. Kedua, berkah agar usaha dagangnya maju. Banyak pedagang berziarah ke makam Sunan Muria untuk memohon berkah agar dagangannya laris dan usahanya maju. Mereka meyakini bahwa berkah wali bisa memberikan dampak pada usaha dagangnya. Persaingan yang ketat dalam dunia perdagangan menjadikan beberapa pedagang mencari cara lain yang bersifat "spiritual" untuk bisa memajukan usahanya. Mereka meyakini agar usaha dagangnya maju, seseorang tidak cukup hanya mengandalkan usaha yang bersifat zahir. Di samping usaha zahir, seperti adanya modal yang cukup, pelayanan yang baik ataupun jaringan yang kuat, pedagang atau pengusaha harus juga mencari cara yang bersifat batin.

Ketiga, berkah agar mendapatkan pekerjaan. Motive in order lain sebagian pelaku ziarah adalah berkah agar mendapatkan pekerjaan dan dimudahkan urusannya. Pengangguran merupakan salah satu permasalahan sosial yang terjadi pada bangsa ini. Pasca menempuh jenjang pendidikan, umumnya mereka tidak lagi mau kembali ke desa dengan menjadi petani. Mereka berharap bisa mendapatkan pekerjaan "kantoran" seperti menjadi pegawai negeri sipil (PNS) atau bekerja di kantor-kantor swasta atau bahkan pabrik. Mereka umumnya tidak mau menjadi petani, karena petani dianggap sebagai pekerjaan "kotor" dan terkesan "rendahan", pekerjaan yang tidak perlu pendidikan, apalagi bagi lulusan perguruan tinggi. Karena jumlah lapangan pekerjaan yang sedikit dan besarnya tenaga kerja bahkan setiap tahun terus meningkat, akhirnya terjadi ketidak seimbangan antara jumlah angkatan kerja dengan lapangan kerja yang ada. Akibatnya persaingan untuk mendapatkan pekerjaan menjadi sangat ketat. Dalam menyikapi persaingan demikian, mereka menempuhnya dengan melakukan banyak cara, dengan harapan bisa mendapatkan pekerjaan. Tidak sedikit dari mereka yang berziarah ke makam Sunan Muria agar mendapatkan berkah bisa mendapatkan pekerjaan diangkat jadi PNS, misalnya. Banyak juga orang yang bernadzar 
sebelumnya, jika ia diangkat jadi PNS atau diterima pada kantor tertentu maka ia akan melaksanakan ziarah ke makam Sunan Muria.

Keempat, berkah mendapatkan jodoh. Bagi para orang tua yang mempunyai anak perempuan dan sudah menginjak usia matang, berharap agar anaknya cepat mendapatkan jodoh atau pasangan hidup. Menurut keyakinan banyak orang, urusan jodoh adalah urusan takdir, Allah yang menentukan semuanya. Oleh karena itu, agar anak perempuan mereka cepat mendapatkan jodoh banyak cara yang dilakukan sebagai ikhtiyar baik yang bersifat zahir maupun bațin. Berziarah ke makam Sunan Muria adalah salah satu cara bațin yang sering dilakukan oleh para orang tua yang menghendaki anakanak perempuannya cepat mendapatkan pasangan dalam hidupnya. Mereka berharap, dengan ziarah ke makam Sunan Muria bisa didapatkan berkah sehingga anak-anak mereka dapat mendapatkan jodoh yang terbaik dan bisa membangun rumah tangga bahagia sampai kakek nenek. Informasi ini peneliti dapatkan dari juru kunci makam Sunan Muria yang sering mendapatkan permohonan dari peziarah agar bisa didoakan dengan harapan tersebut. Biasanya mereka menyatakannya dengan malu-malu maksud kedatangannya ke makam Sunan Muria. ${ }^{6}$

Kelima, berkah keluarga sakinah dan bahagia. Bagi para peziarah yang sudah berkeluarga, umumnya mereka berdoa mengharap berkah di makam Sunan Muria agar keluarganya mendapatkan kebahagiaan. Keutuhan dan kebahagiaan keluarga menjadi motive in order dalam ziarahnya. Dewasa ini ada kecenderungan grafik keretakan rumah tangga meningkat. Banyak pasangan keluarga yang merasa khawatir akan terjadinya keretakan dalam rumah tangganya. Agar keluarganya utuh, banyak masyarakat yang melakukan ziarah ke makam Sunan Muria mengharap berkah keluarga sakinah dan bahagia. Pak Shohib bercerita, kebanyakan pasangan keluarga yang berziarah minta didoakan agar keluarganya bisa tetap utuh dan bahagia. Pernah ada seorang ibu yang datang karena sedang mengalami masalah keluarga, suaminya mau menceraikannya karena mau menikah lagi. la berziarah ke makam Sunan Muria dan minta didoakan agar suaminya dan keluarganya bisa kembali seperti semula. Pernah juga ada peziarah, seorang janda yang mau menikah lagi. Dia datang ke makam Sunan Muria minta didoakan agar

${ }^{6}$ Wawancara dengan M. Shohib, juru kunci makam Sunan Muria tanggal 2 September 2010. 
pernikahan keduanya nanti bisa langgeng. Dia berharap, suami yang keduanya bisa menjadi pemimpin bagi keluarganya dan menjadi suami yang bertanggungjawab. ${ }^{7}$

Jika dijabarkan satu persatu motive in order peziarah yang datang ke makam Sunan Muria sungguhlah amat banyak. Bisa jadi setiap orang mempunyai motif sendiri-sendiri. Hal ini diakui oleh M. Shohib, juru kunci makam Sunan Muria. Orang-orang yang berziarah ke makam Sunan Muria mempunyai latar belakang yang berbeda-beda, ada pengusaha, pedagang, petani, pegawai negeri, buruh, pejabat, DPR dan sebagainya. Masing-masing mempunyai tujuan sendiri-sendiri, sesuai dengan kebutuhannya. Jika pedagang atau pengusaha, mereka umumnya minta didoakan agar usahanya lancar dan maju. Petani minta didoakan agar tanamannya selamat dan menghasilkan panen yang melimpah. Pegawai, minta didoakan agar bisa mendapatkan jabatan atau selamat dalam jabatannya dan sebagainya. Mereka percaya bahwa berziarah ke makam Sunan Muria adalah cara yang dianggap tepat untuk menyampaikan hajat. Paling tidak, cara ini bisa membuat hati mereka lebih tenang. ${ }^{8}$

Makam lain yang juga ramai dikunjungi peziarah adalah makam Syekh Syadzali. Sejarah Syeh Sadzali sendiri sampai sekarang masih penuh misteri. Masyarakat meyakini kalau Syeh adalah salah satu murid Sunan Muria yang konon berasal dari Irak (Baghdad) dan mempunyai ilmu linuwih yang sangat tinggi. Dia adalah salah satu murid yang kinasih karena memegang peranan penting ketika Sunan Muria beradu kesaktian dengan Dampo Awang. Peziarah yang datang ke makam Syekh Syadzali berasal dari berbagai daerah seperti Pati, Kudus, Jepara, Demak, Surabaya bahkan Jakarta. Berbeda dengan motive in order pelaku ziarah ke makam Sunan Muria, umumnya peziarah ke makam Syekh Syadzili lebih mengkhususkan pada motif keilmuan, khususnya ilmu kebatinan atau kanuragan. Peziarah yang datang ke makam Syekh Syadzili tidak sebanyak peziarah ke makam Sunan Muria. Mereka umumnya orang-orang yang sedang menjalani lakon, yakni sejenis ritual yang bertujuan untuk penguasaan suatu ilmu (ilmu kanuragan). Menurut penuturan juru kunci makam Syekh Syadzili, Bukhori (45 th), peziarah ke makam Syekh

7 Wawancara dengan M. Shohib tanggal 2 September 2010.

8 Wawancara dengan M. Shohib tanggal 2 September 2010. 
Syadzili umumnya punya hajat untuk mendapatkan ilmu linuwih, seperti ilmu ketabiban atau ilmu kanuragan bahkan perdukunan. Mereka biasanya melakukan ritual nelik atau semedi, yakni berdiam diri di sekitar makam Syekh Syadzali sampai berhari-hari, ada yang satu hari satu malam, ada tiga hari tiga malam bahkan ada yang sampai satu minggu. Dalam ritual neliknya, mereka berharap bisa mendapatkan pengajaran ilmu linuwih langsung dari Syekh Syadzali. Di samping itu peziarah yang datang ke makam Syekh Syadzili sebagian ada yang mempunyai tujuan mencari obat atas penyakit yang dideritanya atau anggota keluarganya. Mereka meyakini berkah ziarah ke makam Syekh Syadzili bisa mengobati penyakitnya. Bahkan di dekat makam Syekh Syadzali terdapat tiga mata air yang memiliki tiga rasa khas dan boleh dibilang ajaib dan dipercaya banyak khasiatnya. Banyak peziarah datang untuk mengambil air tersebut sebagai obat untuk segala jenis penyakit.9

Peziarah yang datang ke makam Sunan Gadung Sosro Kusumo dan Sunan Gading umumnya orang dari sekitar Muria. Orang-orang Colo dan sekitarnya jika mereka punya hajat seperti hendak menikahkan anaknya atau memulai pekerjaan dagang, atau hendak membangun rumah biasanya terlebih dahulu ziarah ke makam Sunan Gadung dan Sunan Gading. Mereka meyakini, berziarah ke kedua makam tersebut dapat memberikan berkah sehingga semua hajatnya bisa berjalan lancar dan tidak ada halangan yang berarti. ${ }^{10}$

Mengurai tentang motive in order dalam ritual ziarah dari masing-masing pelaku ziarah ke makam-makam yang dianggap suci di Muria dapat dibedakan dalam dua kategori, yakni yang bersifat teogenetis dan biogenetis. Untuk lebih jelasnya motive in order pelaku ziarah pada masing-masing makam di Muria dapat ditabulasikan sebagai berikut:

\footnotetext{
${ }^{9}$ Wawancara dengan Bukhori, juru kunci makam Syekh Syadzali tanggal 2 September 2010.

10 Wawancara dengan Masthur, juru kunci makam Sunan Gading dan Sunan Gadung tanggal 2 September 2010.
} 
Tabel 1.

Motive in Order Pelaku Ziarah pada Makam-makam di Muria

\begin{tabular}{|c|c|c|}
\hline \multirow{2}{*}{ Makam } & \multicolumn{2}{|c|}{ Motive in Order } \\
\hline & Teogenetis & Biogenetis \\
\hline Sunan Muria & $\begin{array}{l}\text { Ibadah, ibrah } \\
\text { keteladanan }\end{array}$ & $\begin{array}{l}\text { Kelancaran dalam } \\
\text { usaha, mendapatkan } \\
\text { pekerjaan, } \\
\text { mendapatkan jodoh, } \\
\text { keluarga bahagia, } \\
\text { mendapatkan jabatan, } \\
\text { mendapatkan } \\
\text { keturunan dan } \\
\text { sebagainya }\end{array}$ \\
\hline Syekh Syadzali & $\begin{array}{l}\text { Penguasaan ilmu } \\
\text { linuwih }\end{array}$ & Mencari kesembuhan \\
\hline $\begin{array}{l}\text { Sunan Gadung dan } \\
\text { Sunan Gading }\end{array}$ & Doa restu & $\begin{array}{l}\text { Keselamatan dan } \\
\text { kelancaran dalam hajat }\end{array}$ \\
\hline
\end{tabular}

Dari tabulasi di atas tampak terdapat perbedaan motif para pelaku ziarah yang datang berziarah ke makam-makam suci di Muria. Jika berziarah ke makam Sunan Muria, kebanyakan motive in order-nya bersifat tabarrukan dengan harapan mendapatkan keselamatan dan kelancaran dalam segala urusan kehidupan; namun motif di makam Syekh Syadzali lebih bersifat untuk mengusai ilmu atau linuwih ataupun mencari kesembuhan. Sedangkan motif peziarah ke makam Sunan Gading dan Sunan Gadung lebih bersifat mohon doa restu dari para anak cucu yang hendak melaksanakan hajat.

Dari paparan di atas dapat disimpulkan bahwa ziarah ke makam-makam orang yang dianggap suci didasari oleh motif-motif yang lahir dari dalam diri para peziarah. Motif-motif ini membentang dari yang bersifat kolektif, yakni motif tradisi atau amalan yang telah menjadi tradisi dari kelompok pendukung kebudayaan ziarah ataupun motif yang bersifat personal yang sifatnya sangat beragam karena latar belakang dan orientasi peziarah yang berbeda-beda. Keseluruhan dari motif peziarah ini umumnya berangkat dari sistem kepercayaan yang meyakini jika makam-makam para wali atau orangorang shaleh itu bersifat sacral dan bisa menjadi media tawassul mereka 
untuk menyampaikan doa dan hajatnya. Para wali adalah mediator yang bisa menghubungkan dalam relasi kepada Allah dan Rasulullah.

\section{Pariwisata Ziarah Makam Muria: Komodifikasi Tradisi}

Makam di samping mempunyai dimensi tradisi yang bersifat spiritual, juga terdapat dimensi pariwisata. Menurut statistik dari Departemen Kebudayaan dan Pariwisata tahun 2005 bahwa lebih dari $63.7 \%$ dari keseluruhan total wisatawan di Jawa lebih memilih mengunjungi makammakam wali, daripada keseluruhan situs seperti candi, museum ataupun situs purbakala lainnya. Data ini cukup memberikan bukti bahwa makam-makam wali sangat potensial sebagai daerah tujuan wisata dan menjadi primadona pariwisata, khususnya di Jawa. Potensi ini tidak lepas dari karakteristik masyarakat Islam Indonesia yang bercorak tradisional yang cenderung toleran terhadap tradisi-tradisi asli, termasuk tradisi ziarah. Pada bagian lain, Islam yang masuk ke Indonesia adalah Islam sufistik yang menempatkan kaum sufi sebagai orang-orang suci yang menempati posisi tinggi dalam sistem kepercayaan masyarakat. Posisi yang diyakini bisa memberikan berkah, shafa'at dan karāmah menjadikan makam para wali menjadi tempat yang sering dikunjungi.

Makam Sunan Muria, Syekh Sadzili dan Sunan Gadung dan Gading adalah makam-makam yang menjadi daerah tujuan para peziarah dalam berwisata spiritual. Menurut data pemerintah Desa Colo, pada tahun 2009 tercatat lebih dari 2.535.000 peziarah atau wisatawan Nusantara dan 725 wisatawan mancanegara. Angka ini lebih tinggi dari data tahun 2008 yang tercatat 2.367.800 wisatawan Nusantara dan 543 wisatawan mancanegara yang berkunjung ke Muria. Dari angka itu lebih dari 85\% wisatawan adalah para peziarah yang datang berziarah ke makam Sunan Muria. Menurut penuturan juru kunci Sunan Muria, para peziarah yang datang ke makam Sunan Muria berasal dari berbagai kota dan daerah yang ada di Indonesia seperti Demak, Pati, Jepara, Semarang, Surabaya, Solo, Bandung Jakarta, Bandung, Tasikmalaya, Palembang, Lampung, Makassar dan sebagainya. Bahkan terdapat juga peziarah dari luar negeri seperti Malaysia, Singapura dan Brunei Darussalam. Besarnya jumlah pengunjung yang berwisata ke Muria, termasuk peziarah ke makam-makam suci Muria menjadikan Muria sebagai andalan pariwisata Kabupaten Kudus. 
Sebagai daerah yang banyak dikunjungi para wisatawan, termasuk peziarah memberikan pengaruh besar terhadap masyarakat sekitar Muria, baik pada aspek ekonomi maupun sosial. Pada dimensi ekonomi, banyak masyarakat Muria yang menggantungkan kehidupannya pada sector ini. Adanya makam "suci" dan potensi wisata lainnya yang berlokasi di Gunung Muria secara ekonomis dapat memberikan lapangan kerja yang besar bagi masyarakat sekitar Muria. Hampir sebagian besar warga Muria, bisa dikatakan menggantungkan kegiatan ekonominya dengan bersandar pada wisatawan dan peziarah yang datang ke makam-makam suci Muria. Mereka mengembangkan jenis usaha yang terkait dengan pariwisata. Menurut data pemerintah desa bahwa jenis usaha yang terkait pariwisata Muria yang menggerakkan perekonomian masyarakat sekitar Colo antara lain usaha penginapan atau homestay (24 unit), transportasi (78 unit angkutan transportasi), warung makam atau rumah makan (189 warung atau rumah makan), kios cindera mata (336 unit), industri kerajinan (11 industri kerajinan dan rumah tangga) dan tukang ojek (391 pengojek). Ini artinya bahwa tenaga kerja yang disedot untuk sektor pariwisata makam Sunan Muria ini lebih dari 1.500 orang setiap harinya. Data di atas belum termasuk jumlah petugas atau pegawai makam, pedagang gendong yang menjajagan dagangan secara asongan, penjual mainan, usaha parkir, usaha kamar mandi ataupun pengemis "permanen" dan musiman yang memanfaatkan ramainya peziarah yang datang ke makam-makam suci Muria.

Di samping bisa mengangkat usaha perdagangan dan jasa di bidang pariwisata, makam-makam suci Muria ternyata juga bisa mengangkat petani di sekitar Muria. Beraneka ragam hasil perkebunan yang diperdagangkan di sekitar makam-makam Muria, tentunya bisa membawa dampat bagi meningkatnya ekonomi dan kesejahteraan petani Muria. Pisang, talas, ganyong, petai, jeruk bali, parijoto, delima adalah buah tangan khas Muria yang sering diburu para peziarah. Bagi sebagian peziarah, jika pulang ziarah ke makam Sunan Muria tidak membawa buah tangan ganyong, rasanya kurang lengkap. Di samping ganyong, buah parijoto adalah khas dan identik dengan Muria. Menurut penuturan warga, buah ini hanya bisa didapati di Muria. Karena buah ini hanya tumbuh di pegunungan Muria. Buah kecil yang rasanya asem ini diyakini para peziarah bisa menyuburkan kandungan, dibutuhkan terutama pasangan yang sulit mendapat keturunan. Bagi ibu yang sedang hamil, dianjurkan juga memakan buah ini, karena bisa menjadikan anak- 
anaknya nanti jika lahir akan berwajah tampan jika laki-laki atau cantik jika perempuan. Banyak para peziarah yang jika ia datang menyempatkan untuk mencari buah-buah di atas sebagai oleh-oleh. Ini artinya, petani Muria juga mendapatkan berkah yang besar dari adanya makam-makam suci Muria.

Banyaknya peziarah yang datang ke makam Sunan Muria dalam setiap tahunnya dapat dibedakan dalam tiga kategori, yakni bulan-bulan ramai, biasa dan sepi. Jika pada bulan-bulan ramai, pengunjung atau peziarah yang datang mencapai ribuan bahkan puncaknya sampai puluhan ribu peziarah dalam setiap harinya, pada hari-hari biasa tidak sebanyak peziarah pada bulan-bulan ramai, peziarah yang datang hanya ratusan sampai ribuan. Sedangkan pada bulan-bulan sepi, tetap ada peziarah yang datang setiap harinya hanya tidak lebih sekitar puluhan sampai ratusan orang. Bulan-bulan ramai peziarah biasanya terjadi pada bulan Syuro, Maulud dan Ruwah; bulan sepi biasanya terjadi pada bulan Apit dan Poso. Selain pada bulan-bulan di atas, peziarah yang datang ke makam Sunan Muria tetap mengalir dan jumlahnya cukupan, seperti pada bulan Sapar, Ba'da Mulud, Jumadil Awal, Jumadil Akhir dan Rajab.

Keberadaan makam-makam suci di Muria dapat mengangkat ekonomi masyarakat Muria dan sekitarnya. Contohnya, tukang ojek pada bulan-bulan ramai peziarah, dalam satu harinya bisa mendapatkan rata-rata Rp. 300.000. Itu artinya setiap pengojek dalam satu bulan, pada bulan-bulan ramai bisa mempunyai pendapatan rata-rata Rp. 9.000.000,-; satu angka yang sangat besar untuk pendapatan seorang pengojek. Pada bulan-bulan biasa, mereka rata-rata tiap bulannya mendapatkan Rp. 4.500.000,-; dan pada bulan-bulan sepi rata-rata tiap bulannya Rp. 2.250.000,-. Karena besarnya pemanfaatan jasa ojek di Muria, menjadikan profesi "ojek" sebagai salah satu pilihan pekerjaan khususnya bagai anak-anak muda sekitar Muria. Di samping waktu kerja yang tidak mengikat, penghasilan dari tukang ojek ini dalam setiap bulannya terbilang besar. Dengan ramainya peziarah ke Muria, ternyata membawa dampak bagi terbukanya kesempatan pekerjaan yang besar bagi masyarakat Muria dan sekitarnya baik dalam bentuk perdagangan ataupun jasa seperti ojek.

Kecenderungan tradisi ziarah ke makam Sunan Muria menjadi sebuah komoditas tampak pada kreasi budaya yang diselenggarakan masyarakat Colo untuk menyelenggarakan even-even tradisi yang berporos pada makam 
Sunan Muria dalam rangka untuk menarik para peziarah datang. Di antara kreasi itu, tampak pada acara buka luwur atau khaul makam Kanjeng Sunan yang dilakukan untuk mengganti kelambu makam. Acara ini bisa menyedot puluhan ribu peziarah yang datang untuk berharap berkah. Banyak para peziarah yang berebut bekas kelambu yang dipakai sebagai penutup makam Kanjeng Sunan. Nilai tradisi yang berisi "ngalap berkah" ini ternyata menjadi ajang komoditi yang bisa ditransaksikan dengan nilai rupiah. Sungguhpun bukan praktek terbuka, transaksi jual beli barang bekas kelambu makam ini cukup membuktikan bahwa dimensi ekonomi turut menjadi bagian bagi prosesi tradisi ziarah makam suci yang "spiritual".

Kreasi budaya Colo lainnya yang merupakan bentuk kreasi komodifikasi tradisi adalah perayaan "syawalan" yang diwarnai kirab seribu ketupat. Perayaan "syawalan" yang diselenggarakan setiap tahun tepat pada seminggu setelah hari raya Idul Fitri ini merupakan bentuk ungkapan rasa syukur warga sekitar Muria. Tradisi ritual ini diwarnai prosesi kirab gunungan seribu ketupat Kanjeng Sunan Muria. Gunungan yang terdiri atas susunan seribu ketupat dan ratusan lepet (jenis makanan dari ketan) diarak dari rumah Kepala Desa setempat sekitar pukul 07.30 WIB, diarak menuju Masjid Sunan Muria. Selanjutnya, dilakukan ritual ziarah ke Makam Sunan Muria, dilanjutkan dengan minum air dan cuci kaki serta tangan dengan air dari gentong peninggalan Sunan Muria dan dilanjutkan dengan penyerahan kupat gunung dari Ketua Yayasan Makam Sunan Muria kepada rombongan.

Dari penjelasan di atas sungguh bahwa ziarah yang pada awalnya sebuah tradisi yang mempunyai akar kesejarahan kepecayaan Jawa, di era pariwisata ini benar telah bergeser menjadi sebuah komodifikasi yang menjual "spiritualitas" sebagai komoditas pariwisata. Potensi tradisi ziarah makammakam suci Muria terbukti sangat besar, di samping bisa menghidupkan dan meramaikan wilayah Muria karena banyaknya peziarah, ternyata hal itu juga berdampak besar bagi gerak ekonomi masyarakat. Pada akhirnya, gejala itu bisa mengangkat kesejahteraan masyarakat sekitar Muria.

\section{E. Dampak Sosial Pariwisata "Spiritual" Ziarah Muria}

Kepercayaan terhadap wali sebagai entitas yang mempunyai karāmah, ilmu linuwih dan bisa memberikan shafä'at mendorong terciptanya tempattempat "suci baru" yang disandarkan pada "agama" besar. Kebutuhan akan 
sesuatu yang sakral untuk media bagi pemenuhan spiritualitas menjadikan tempat-tempat sacral yang disandarkan akan karamah dan syafa'at wali menjadi tempat yang dikunjungi peziarah sebagai pendukung budayanya. Potensi yang besar dari makam-makam suci Muria, menjadikan masyarakat Muria sadar jika mereka menggantungkan mata pencahariannya dengan wisata ziarah. Secara teoritik gejala ini merupakan bentuk komodifikasi tradisi ziarah. Ziarah ke makam suci sebagai sebuah tradisi ternyata turut menciptakan bentuk-bentuk usaha yang bisa menjadi komoditi yang mempunyai nilai ekonomi tinggi. Sebagai sebuah tradisi, ziarah ke makam suci mempunyai akar kesejarahan yang panjang sebagai warisan leluhur yang mengandung nilai penghormatan pada roh-roh suci. Tingginya peziarah yang datang ke Muria menyebabkan orang-orang sekitar Muria mengambil keuntungan dari tradisi ziarah ini dengan berdagang dan menjual jasa. Berkat adanya makam suci di Muria, berbagai usaha dan barang di Muria bisa menjadi komoditas yang dijualbelikan.

Bergesernya Muria menjadi daerah tujuan wisata membawa dampak besar bagi dinamika sosial masyarakat sekitar Muria. Di samping Muria menjadi pusat kegiatan ekonomi, kondisi ini berpengaruh pada sosial masyarakat sekitar Muria. Diantara dampak sosial yang bisa dijelaskan sebagai akibat "komodifikasi" tradisi ziarah adalah sebagai berikut: pertama, menguatnya solidaritas lokal untuk bisa mengangkat Muria sebagai tempat yang menarik dikunjungi peziarah. Munculnya kesadaran kolektif itu mendorong munculnya tanggung jawab bersama untuk menjaga dan merawat Muria sebagai tempat yang nyaman untuk dikunjungi. Hal ini disebabkan oleh adanya kesadaran bersama bahwa Muria adalah rumah bersama, tempat mereka menggantungkan ekonomi keluarga masyarakat sekitar Muria. Oleh karena itu, kesadaran bersama ini didasari oleh munculnya kepentingan bersama yang porosnya bergantung pada keberfungsian Muria. Berbagai contoh kesadaran kolektif masyarakat Muria ini diantaranya ketentuan untuk wajib mengikuti kerja bakti sosial yang dilaksanakan setiap hari minggu, ketentuan larangan menebang pohon sembarangan, kesadaran berinfak untuk pembangunan sekitar Muria.

Kedua, munculnya kompetisi antar masyarakat Muria, masing-masing untuk bisa merebut pasar Muria. Bergesernya Muria menjadi "pasar", pusat transaksi antara penjaja barang dan jasa dengan peziarah memposisikan 
Muria seakan menjaga pasar bebas. Dalam pasar ini, para pelaku ekonomi Muria bebas berkreasi untuk bisa menjaring peziarah sebesar-besarnya melalui barang dan jasa yang mereka tawarkan sebagai komoditas ekonomi. Indikasinya tampak seperti persaingan para penjual jasa parkir. Perang tarif menjadi gejala umum dalam rangka menarik para peziarah. Belum lagi kenyamanan dan berbagai kemudahan yang ditawarkan para penjual jasa. Para pemilik warung makam, mereka berlomba untuk menarik pembeli dengan pelayanan sebaik mungkin. Ada yang menggunakan "tempat" yang menarik, tarif murah, area parkir luas, ataupun jaminan rasa yang dipromosikan secara terbuka. Secara sosial, terjadi perang "promosi" yang cukup bebas antar pelaku ekonomi di Muria.

Ketiga, terbukanya lapangan kerja yang luas di Muria menjadikan masyarakat Muria cenderung berpandangan pragmatis. Kecenderungan ini tampak pada banyaknya orang tua yang mempekerjakan anak-anaknya, meskipun usianya masih anak-anak. Sebagian anak ada yang berdagang, menawarkan jasa toilet, atau bahkan tidak sedikit anak-anak yang menjadi pengemis di sepanjang jalan menuju makam Sunan Muria. Karena pandangan pragmatis para orang tua yang demikian banyak anak-anak putus sekolah karena lebih tertarik menjadi penjual jasa atau barang di Muria. Pandangan orang tua yang seperti ini berpengaruh pada masa depan anak-anak mereka. Anak-anak ini kehilangan masa bermainnya. Pada usia yang masih kanakkanak, mereka harus turut membanting tulang untuk meringankan beban orang tuanya.

Dari gambaran di atas dapat disimpulkan bahwa dampak sosial sebagai akibat berkembangnya tradisi ziarah dan pariwisata di Muria diantaranya menguatnya solidaritas lokal, munculnya kompetisi antar masyarakat Muria, terbukanya lapangan kerja yang luas di Muria menjadikan masyarakat Muria cenderung berpandangan pragmatis. Untuk dampak pertama dan kedua bersifat positif pada masyarakat namun untuk dampak ketiga bersifat negatif.

\section{F. Kesimpulan}

Dari keseluruhan pembahasan pada bab-bab diatas dapat disimpulkan sebagai berikut: pertama, ziarah adalah sebuah aktivitas yang mempunyai tujuan-tujuan yang lahir dari motivasi para pengamalnya. Motif-motif ini membentang dari yang bersifat kolektif, yakni motif tradisi pendukung 
kebudayaan ziarah ataupun motif yang bersifat personal tergantung orientasi peziarah yang berbeda-beda. Keseluruhan dari motif peziarah ini umumnya berangkat dari sistem kepercayaan yang meyakini jika makam-makam para wali atau orang-orang shaleh itu bersifat sakral dan bisa menjadi media tawassul mereka untuk menyampaikan doa dan hajatnya. Para wali adalah mediator yang bisa menghubungkan dalam relasi kepada Allah dan Rasulullah. Motive in order para pelaku ziarah yang datang ke makam Sunan Muria, kebanyakan bersifat "tabarrukan" dengan harapan mendapatkan keselamatan dan kelancaran dalam segala urusan kehidupan seperti kelancaran dalam usaha, mendapatkan pekerjaan, mendapatkan jodoh, keluarga bahagia, mendapatkan jabatan, mendapatkan keturunan dan sebagainya. Motive in order peziarah di makam Syekh Syadzali lebih bersifat untuk mengusai ilmu atau linuwih ataupun mencari kesembuhan. Sedangkan motif peziarah ke makam Sunan Gading dan Sunan Gadung lebih bersifat mohon doa restu dari para anak cucu yang hendak melaksanakan hajat.

Kedua, makam Sunan Muria, Syekh Syadzili dan Sunan Gadung dan Gading adalah makam-makam yang menjadi daerah tujuan para peziarah dalam berwisata spiritual. Pada tahun 2009 tercatat lebih dari 2.535.000 peziarah atau wisatawan Nusantara dan 725 wisatawan mancanegara. Sebagai daerah yang banyak dikunjungi para peziarah memberikan dampak terhadap masyarakat Muria, baik ekonomi maupun sosial. Pada aspek ekonomi sebagian besar warga Muria bersandar pada pariwisata makammakam suci Muria, dengan melakukan berbagai usaha ekonomi seperti penginapan (24), transportasi (78), warung atau rumah makan (189), kios cindera mata (336), industri kerajinan (11) dan tukang ojek (391). Dalam setiap harinya lebih dari 1.500 tenaga kerja yang menggantungkan kegiatan ekonominya di Muria. Kondisi ini juga membawa dampak sosial sebagai akibat berkembangnya tradisi pariwisata ziarah diantaranya menguatnya solidaritas lokal, munculnya kompetisi antar masyarakat Muria, terbukanya lapangan kerja yang luas di Muria menjadikan masyarakat Muria cenderung berpandangan pragmatis.[w] 


\section{BIBLIOGRAFI}

Abdul Kholiq, "Paradigma Spiritualitas dalam Tradisi Sinoman: Pengamatan Atas Tradisi Sinoman dalam Masyarakat Demak," Laporan Penelitian Individual, Semarang: Pusat Penelitian IAIN Walisongo, 2002

Abdul Muhaya dkk., "Paradigma Spiritual dalam Gerakan Politik," Laporan Penelitian Kolektif Kompetitif Depag RI, tidak diterbitkan, Semarang: Pusat Penelitian IAIN Walisongo, 2001.

Abdullah Irwan, Konstruksi dan Reproduksi Kebudayaan, Yogyakarta: Pustaka Pelajar, 2006.

Ahmad Najib Burhani, Sufisme Kota, Berpikir Jernih Menemukan Spiritual Positif, Jakarta: Serambi, 2001.

Clifford Geertz, Abangan, Santri, Priyayi dalam Masyarakat Jawa, Bandung: Pustaka Jaya, 1981.

Elly Setiadi dkk, Ilmu Sosial dan Budaya Dasar, Jakarta: Kencana, 2007.

Foley, W. A., Anthropological Linguistics: an Introduction. Oxford: Blackwell, 1997.

Henri Chambert-Loir dan Claude Guillot, Ziarah dan Wali di Dunia Islam, Jakarta: Serambi, Forum Jakarta Paris dan EFEO, 2003.

http://www.republika.co.id/koran_detail.asp?id=248849\&kat_id=13, diakses pada tanggal 17 Juni 2006.

Imam Sanusi, HM., Perjuangan Syaikh K.H. Ahmad Mutamakkin, Kajen-Pati: tanpa penerbit, 1428H/2007.

Jeffrey Lang: Struggling to Surrender and Even Angels Ask: A Journey to Islam in America, Diterjemahkan, Bahkan Malaikat pun Bertanya: Membangun Sikap Islam yang Kritis, Jakarta: Serambi, 2001.

Kaplan, D., dan Albert, A. M. 1999. Teori Budaya. Diterjemahkan oleh Landung Simatupang. Yogyakarta: Pusat Pelajar.

Koentjaraningrat, Kebudayaan Jawa, Jakarta: Pustaka Jaya, 1984.

Kebudayaan, Mentalitas dan Pembangunan di Indonesia, Jakarta: Gramedia Pustaka Utama, 1992.

Walisongo, Volume 20, Nomor 2, November 2012 
Pengantar Ilmu Antropologi, Jakarta: Radar Jaya Offset, 2000.

Leonard Siregar, "Antropologi dan Konsep Kebudayaan," Jurnal Antropologi Papua, vol. 1, no. 1, Agustus, 2002.

Lihat Rohidi, Tjetjep Rohendi, Ekspresi Seni Orang Miskin: Adaptasi Simbolik terhadap Kemiskinan, Bandung: Penerbit Nuansa, 2000.

Mark R. Woodward, Islam Jawa: Kesalehan Normatif versus Kebatinan, Yogyakarta: LkiS, 1999.

Mawla Abdul Rahman al Jami, Ensiklopedi Tokoh Sufi, Yogyakarta, Beranda, 2007

Naisbitt \& Patricia Aburdene, Megatrend, 2000.

Nur Syam, Islam Pesisiran, Jogyakarta: LKIS, 2005.

Peter C. Hill and Ralph W. Hood, Measures of Religiousity, Birmingham, Alabama: Religious Education Press, 1999.

Profile Desa Colo, 2009.

Robert Hefner, Geger Tengger: Perubahan Sosial dan Perkelahian Politik, Yogyakarta: Lkis, 1999.

Ruslan dan Arifin Suryo Nugroho, Ziarah Wali; Wisata Spiritual Sepanjang Masa, Yogyakarta: Pustaka Timur, 2007.

S. Soebardi, Serat Cabolek: Kuasa, Agama, Pembebasan: Pengadilan K.H. A. Mutamakin dan Fenomena Syaikh Siti Jenar, Bandung: Nuansa, 2004.

Seyyed Hossein Nasr, The Garden of Truth Mereguk Sari Tasawuf, Mizan, Bandung, 2010.

Sudikan, S. Y. Metode Penelitian Kebudayaan, Surabaya: Unesa Unipress bekerja sama dengan Citra Wacana, 2001.

Sunardjo, H., Ramayana Indonesian Wayang Show, Jakarta: Djambatan, 1997.

Suwardi Endraswara, Falsafah Hidup Jawa, Tangerang: Cakrawala, 2003.

Wawancara dengan Bukhori, tanggal 2 September 2010.

Wawancara dengan Fatkhul Muarif tanggal 3 September 2010.

Wawancara dengan Hadi Pujowiyono, tanggal 18 September 2010.

Wawancara dengan Ibu Sunarti (43) tanggal 2 September 2010.

Wawancara dengan Kepala Desa Colo, pada tanggal 18 September 2010 . 
Wawancara dengan M. Shohib, juru kunci makam Sunan Muria, tanggal 2 September 2010.

Wawancara dengan Masthur, juru kunci makam Sunan Gadung, tanggal 2 September 2010.

Wawancara dengan Pak Jaya (38) tanggal 2 September 2010.

Wawancara dengan Pak Saifullah, petani asal Demak tanggal 1 September 2010.

Wawancara dengan Pak Sudadi (40) tanggal 2 September 2010. 
